\title{
寄書
}

\section{動圧空気軸受支持された高速フレキシブル ディスク機構の基本特性*}

保 坂 寛** 石 井 克 典***

Key words : magnetic recording, flexible disk, air bearing, slotted spherical slider, noncontact scanning

\section{1.はじめに}

近年,フレキシブルディスク装置に対する,小型ハー ドディスクなみの高速，大容量，高信頼化の要求が高 まっている。これを実現するためには，ディスクと微 小なすきまを隔てて高速走査するへッドと，ディスク を非接触に支持し回転を安定化させる機構が必要であ る。本研究では，ディスク支持機構に正圧スラスト軸 受を卓, ヘッドに球面溝付きスライダを2)用いた，非接 触支持走査フレキシブルディスク機構の基本特性を報 告する，以下では，試作した機構の基本構成，ディス ク支持力の解析結果，スライダ・ディスク間浮上すき まおよび電磁変換特性の測定結果を示し，本機構によ 门安定した記録再生系が構成できることを示す。

\section{2. ディスク支持系の解析}

\section{1 基 本 構成}

浮上系の基本構成を図 1 に, 主な諸元を表 1 に示す. 回転数と記録密度は, 小型ハードディスクとインタ フェースを一致させるため，それぞれ $3600 \mathrm{rpm}$ およ び $630 \mathrm{bpm}$ （トラック半径 $R=21 \mathrm{~mm} ）$ としている. また，スライダ・ディスク間浮上すきまは，前記記録 密度を達成するため, $0.1 \sim 0.15 \mu \mathrm{m}$ を目標としてい 万.

ディスクはハブを介してモータに接続され，ディス クの両側にはスラスト板が配置されている。一方のス ラスト板には，ヘッド一体形のスライダが突き出る穴 が設けてある、スライダは回転へッド形磁気テープ装 置のスライダ2) と類似の構造を有し，走査方向の 2 本 のスロットを有している。

* 原稿受付 昭和 62 年 5 月 9 日. 昭和 62 年度精密工学会 春季大会学術講演会（昭和 62 年 3 月 28 日）にて発表

** 正 会 員 日本電信電話 (株) (武蔵野市緑町 3-9-11)

*** 日本電信電話 $($ 株)
スラスト板は扇形のグルーブと直線および円形のス ロットを有し，ディスクとの間に 4 個の動圧ポケット 軸受を形成している。スロットは十分に深く，ここで の空気圧力は常に大気圧となっている、ディスクが回 転すると空気の粘性力により，グルーブ後端のステッ プで空気圧力が高まり，ディスクの初期たわみやフ ラッタが抑圧される構造となっている.

\section{2 ディスク支持力の解析}

本方式の有効性を確認するため, 従来形の非接触 ディスク支持機構であるバックプレート形 ${ }^{3)}$ と，スラ

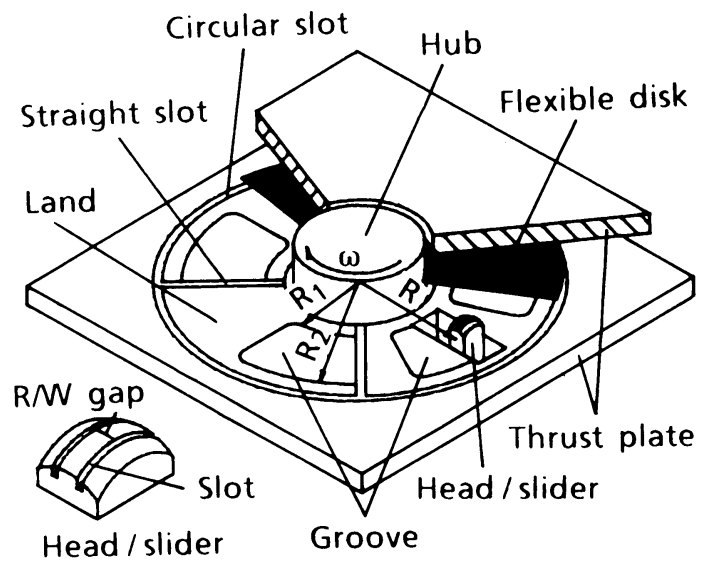

Fig. 1 Configuration of flexible disk drive

Table 1 Specifications

\begin{tabular}{l|l}
\hline Disk radius & $43 \mathrm{~mm}$ \\
Rotating velocity $\omega$ & $3600 \mathrm{rpm}$ \\
Recording density $D(R=21 \mathrm{~mm})$ & $630 \mathrm{bpm}$ \\
Disk flying height & $0.1-0.15 \mu \mathrm{m}$ \\
Disk thickness & $40 \mu \mathrm{m}$ \\
Inner groove radius $R_{1}$ & $20 \mathrm{~mm}$ \\
Outer groove radius $R_{2}$ & $38 \mathrm{~mm}$ \\
Groove depth & $40 \mu \mathrm{m}$ \\
Slider curvature & $20 \mathrm{~mm}$ \\
\hline
\end{tabular}




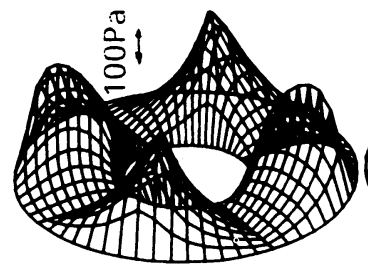

$\mathrm{P}=250 \mathrm{~Pa} \mathrm{~W}=0.32 \mathrm{~N}$

Presented type

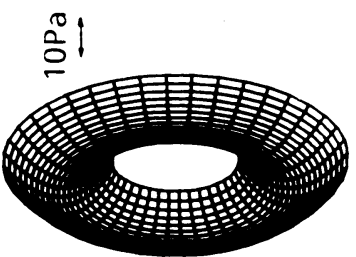

$P=-9.6 \mathrm{~Pa} W=-0.032 \mathrm{~N}$

Fig. 2 Disk supporting pressure

スト板によるディスク支持力を比較する。バックプ レート形はディスクの片側に平坦なスラスト板を有 し，空気の慣性力によりディスクを支持する。

ディスク支持力を定量的に求めるためには，ディス ク変形抢よびスライダ突出し穴の影響を考慮して空気 圧力を解析しなければならないが，本稿では，慣性力 と粘性力という両形態の圧力発生メカ二ズムの差のみ を比較するため，これらの影響を無視する。本方式に 対しては粘性力のみ考慮し, 通常の 2 次元レイノルズ 方程式により，バックプレート形に対してはPelech ら ${ }^{4)}$ に従い，遠心力を考慮した軸対称レイノルズ方程 式により解析した。また境界条件は，本方式に対して はディスク内外周およびスロット部で圧力 0 , バック プレート形に対しては,ディスク内外周で圧力 0 とし， ディスク・スラスト板間すきまは $80 \mu \mathrm{m}$ で一定とし た。

解析結果を図 2 に示す。本方式では，グルーブ後端 で最大となる正の圧力が,バックプレート形では, ディ スク中周付近で最大となる負の圧力が発生している. 最大圧力 $P$ および負荷容量 $W$ の絶対值は，ともに本 方式の方が約 1 けた大きい.すなおち，本方式の方が 約 1 けたディスク支持力が大きく，安定な浮上特性が 得られることが分かる。

\section{3. 浮上特性および電磁変換特性}

\section{1 浮上特性}

図 4，5に示すように，スライダスロット間隔 $l$, ス ラスト板間隔 $X$, 八ブ高さ $Y$, 上側スラスト板・スラ イダ間すきま $Z$ が浮上すきまに及ぼす影響を実験に より求め, 最適な浮上系の設計指針を求める. なお他 の寸法諸元は表 1 に示す值に固定する.

実験装置の構成を図 3 に示す, 浮上すきまは単色光 の干渉輝度により測定した ${ }^{5}$. すなわちスライダをガ ラスで作製し, キセノン管とフィルタで発生した単色 光をスライダ面とディスク面で干渉させ, 干渉輝度を 顕微鏡とテレビカメラでとらえ，計算機内ですきまに

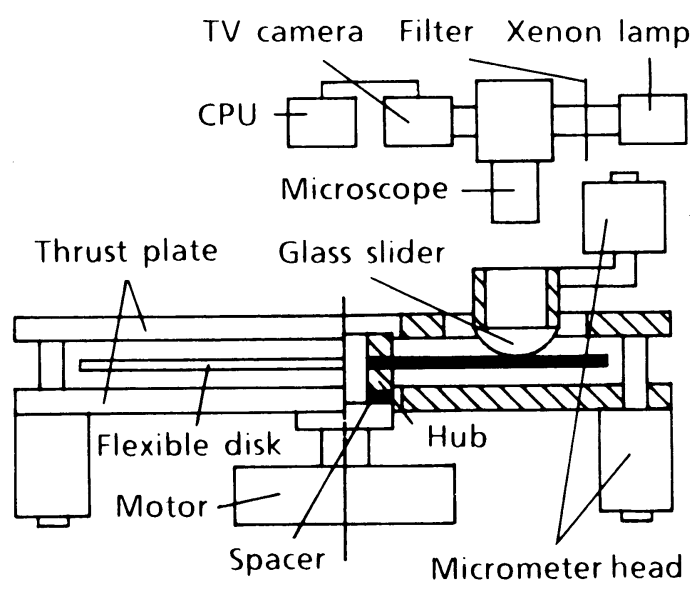

Fig. 3 Experimental apparatus

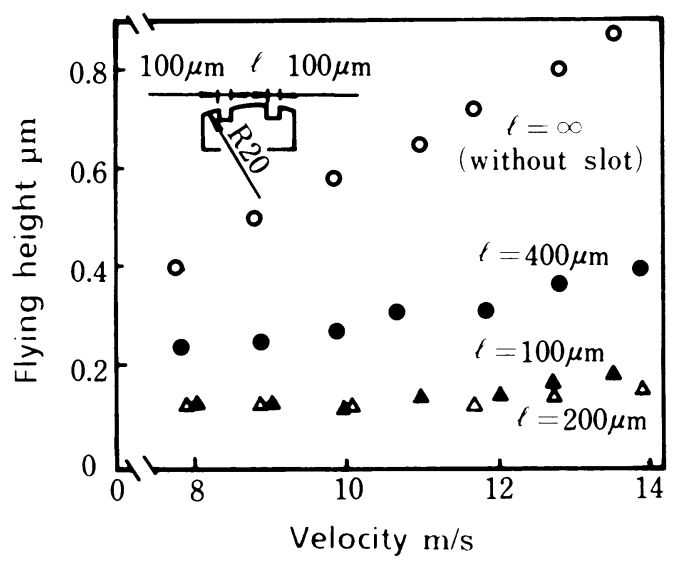

Fig. 4 Effect of land width $l$ on flying height $X=200 \mu \mathrm{m}, Y^{r}=80 \mu \mathrm{m}, Z=60 \mu \mathrm{m}, R=31 \mathrm{~mm}$

変換した。 $X$ および $Z$ はマイクロメータヘッドによ り， $Y$ は八ブ・モー夕軸間のスペーサにより変化させ た。また のの影響は，スロット無し抢よび $l=100,200$, $400 \mu \mathrm{m}$ のスライダにより測定し，スロット幅はす心゙ て $100 \mu \mathrm{m}$ とした.

まず初めに，浮上すきまへの影響が最も大きいと考 えられるlの影響を測定した。結果を図 4 に示寸。横 軸の走査速度 $8 \mathrm{~m} / \mathrm{s}$ はトラック半径 $R=21 \mathrm{~mm}$ にお ける， $14 \mathrm{~m} / \mathrm{s}$ は $R=37 \mathrm{~mm}$ に打ける走査速度にほ济 一致する、スロット無しおよび $l=400 \mu \mathrm{m}$ のスライダ では, $8 \mathrm{~m} / \mathrm{s}$ で浮上すきま間がそれぞれ $0.4 \mu \mathrm{m}, 0.23$ $\mu \mathrm{m}$ あり, 速度の増加と共に直線的に増扣している。 寸きまが過大であるだけでなく，トラック位置により すきまが変化することが分かる，l=100 $\mu \mathrm{m}, 200 \mu \mathrm{m}$ のスライダでは, 走査速度 $12 \mathrm{~m} / \mathrm{s}$ 以上でややすきま が大きいが，それ以下では $0.1 〜 0.15 \mu \mathrm{m}$ の一定すき まが得られている。以上から，lは100～200 $\mu \mathrm{m}$ とす 


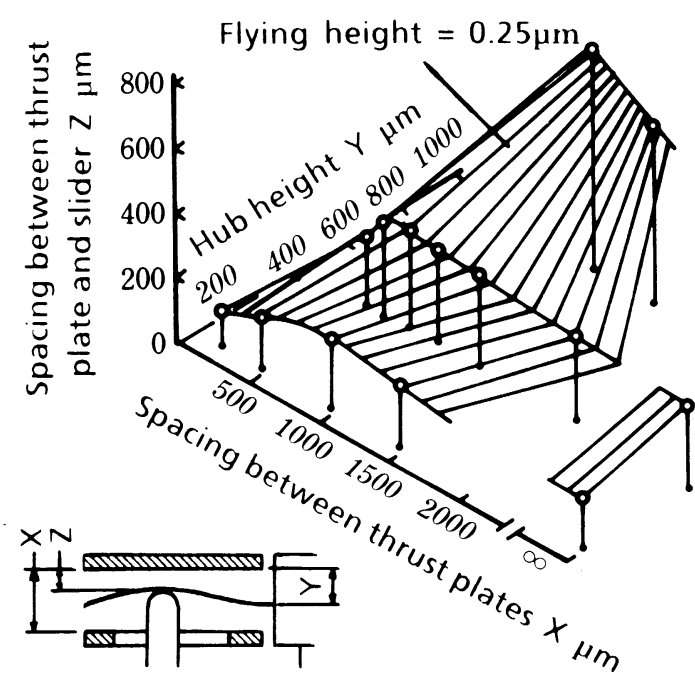

Fig. 5 Effect of disk supporting condition on flying height

$l=100-200 \mu \mathrm{m}, R=30 \mathrm{~mm}, \omega=3600 \mathrm{rpm}$

れ桹いことが分かる。

次に上記スライダを用い, $X, Y, Z$ が浮上すきまに 及ぼす影響を測定した。これらは，スラスト板の反り やディスクローディングのばらつきにより変動するた め, 許容誤差が大きい条件を求める必要がある。本研 究では各パラメー夕の影響を定性的に把握するため, 浮上寸きまが, 測定の容易な, 単色光の $1 / 2$ 波長 $(0.25$ $\mu \mathrm{m})$ 以下とな子領域を求めた。結果を図 5 に示す. ハッチング面の下側がすきま $0.25 \mu \mathrm{m}$ 以下の領域を 表す， $Z$ は小さいほど， $Y$ は大きいほど， $X$ は 1000 $\mu \mathrm{m}$ 付近で，もっとも許容值が大きくなっている．上 側スラスト板とスライダの接触，および，ディスクと 下側スラスト板との接触を考慮し, 最終的な設計值と して， $X=1000 \mu \mathrm{m}, Y=500 \mu \mathrm{m}, Z=90 \mu \mathrm{m}$ を採用

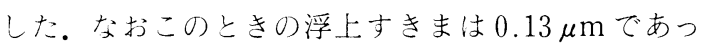
た。

\section{2 電磁变換特性}

前節で決定した浮上機構に実へッドを搭載し，電磁 変換特性を測定した。再生波形を図 6 に示す。振幅変 動のない平坦なエンベローブが得られている。この結 果から, 動的浮上量変動が無い, 安定な記録再生系が 構成されていることが分かる。

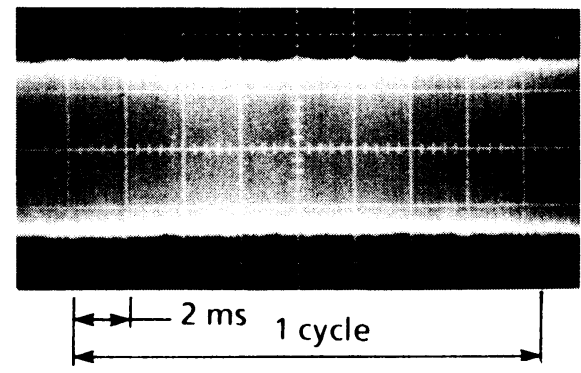

Fig. 6 Reproduced signal $R=25 \mathrm{~mm}, \quad D=530 \mathrm{bpm}$

4. ま と め

スラスト軸受と球面溝付きスライダにより, ディス クを非接触に支持走査する高速フレキシブルディスク 機構の基本特性を報告した。空気圧力の解析による従 来機構とのディスク支持特性の比較, 浮上すきま測定 による浮上系設計指針の提示を行うとともに，電磁変 換特性の測定により安定な記録再生信号が得られるこ とを示した。

本方式は非接触走査であるが微小すきまのため, 空 気中の浮遊じんあいによるクラッシュが予想される。 また，ポケット形状やディスク厚等を含めた最適設計 を行うためには，定量的な浮上特性の解析が必要であ り,これらは今後の課題である。

最後に, 本研究を進めるに当たり, 方式を検討され た, NTT 電気通信研究所 - 原主幹研究員, 新居主幹 研究員, 飯島主任研究員, ならびに実験装置を設計さ れた小口主任研究員に感謝致します。

\section{参 考 文 献}

1）金子礼三，小口重光：可撓円板を記録媒体に用いたディス クメモリの試作, 電子通信学会磁気記録研究会資料, MR 71, 3 (1971) 1.

2) F. W. Hahn : Design Considerations for a Helical-scan Recording Head Contour, Proc. Conf. Video \& Data Rec., (1976) 261.

3) R. T. Pearson: The Development of the Flexible-disk Magnetic Recorder, Proc. IRE, 49, 1, (1961) 164.

4) I. Pelech \& A. H. Shapiro : Flexible Disk Rotating on a Gas Film Next to a Wall, Trans. ASME, 31. Ser. E, 4, (1964) 577 .

5）水川真, 保坂 寛, 原 臣司：球面フォイル軸受の研究 (第 4 報) 一一軸受押込量が大きい場合の実験と解析, 日本 機械学会論文集 (C 編)，51，461（1985）104. 